\title{
Antigenic characterization of Vibrio anguillarum - related organisms isolated from turbot and cod
}

\author{
Ysabel Santos*, Francisco Pazos, Soledad Nuñez, Alicia E. Toranzo \\ Departamento de Microbiología y Parasitología, Facultad de Biología, Universidad de Santiago, \\ E-15706 Santiago de Compostela, Spain
}

\begin{abstract}
This work reports on the antigenic characterization and virulence for rainbow trout Oncorhynchus mykiss of Vibrio anguillarum-related (VAR) strains isolated from diseased turbot Scophthalmus maximus and cod Gadus morhua in Spain and Denmark. These vibrio strains belong to Vibrio splendidus biovar I (serogroups B, C, D, F and G) and $V$. pelagius biovar I (serogroup A). The pathogenicity assays demonstrated that 10 of $15(67 \%)$ VAR strains tested were virulent for rainbow trout, showing an $\mathrm{LD}_{50}\left(50 \%\right.$ lethal dose) ranging from $8.4 \times 10^{3}$ to $7 \times 10^{5} \mathrm{CFU}$ (colony forming units) per fish. Moreover, all the $V$. splendidus biovar I strains of serogroup $F$, which is the predominant type among strains isolated from cod, were virulent for rainbow trout, whle $V$. splendidus biovar I strains isolated from turbot were avirulent. Analysis of lipopolysaccharides (LPS) and membrane proteins showed that VAR strains belonging to different serogroups possessed distinct electrophoretic banding patterns. The immunoblot analysis demonstrated a high immunorelation among VAR strains of the same scrogroups, while strains from different serogroups were not immunologically related. Immunoblot assays also confirmed the dissimilarities in LPS structure observed among the distinct subgroups of serogroup $F$ These findings suggest that present vibriosis vaccines for cod could be improved if $V$. splendidus biovar I representative of serogroup $F$ (subgroups $\alpha$ and $\beta$ ) were tested in trial vaccines.
\end{abstract}

KEY WORDS: Vibro anguillarum-related organisms Turbot - Cod LPS Proteins - Virulence

\section{INTRODUCTION}

Vibrio anguillarum (serotypes $\mathrm{O} 1$ and $\mathrm{O} 2$ ) is the main causative agent of vibriosis among cultured marine fish, particularly turbot Scophthalmus maximus and cod Gadus morhua, in European countries (Toranzo \& Barja 1990, Larsen et al. 1994). Immunization of turbot with vaccines which contain antigen preparations of $V$. anguillarum serotypes $\mathrm{O} 1$ and $\mathrm{O} 2$ and vaccination of cod with monovalent vaccines containing formalin-killed bacteria representative of $V$. anguillarum serotype $\mathrm{O} 2$ have proved to be effective for the control of vibriosis caused by these serotypes (Myhr et al. 1991, Santos et al. 1991, Knappskog et al. 1993). However, $V$. splendidus biovars I and II and other $V$. anguillarum-related (VAR) species, commonly considered environmental strains without pathogenic im-

\footnotetext{
•E-mail: mpaetjlb@usc.es
}

portance, have been isolated from vaccinated farmed turbot (both adults and fry) and cod during disease outbreaks (Toranzo et al. 1990, Myhr et al. 1991, Knappskog et al. 1993, Pazos et al. 1993, Santos et al. 1996). VAR organisms of possible clinical significance have also been isolated from other marine fish species such as sea bass Dicentrarchus labrax and sole Solea solea as well as from diseased crustaceans and molluscs (Baticados et al. 1990, Myhr et al. 1991, Castro et al. 1992, Riquelme et al. 1995), but these microorganisms appeared to be of no clinical importance among farmed salmonid fish (Myhr et al. 1991). Despite an increasing number of reports that describe the isolation of VAR organisms in association with diseased fish and shellfish, few efforts (Pazos et al. 1993, Riquelme et al. 1995) have been made in order to assess the precise role of these bacteria as primary pathogens.

The VAR organisms can be differentiated from Vibrio anguillarum on the basis of biochemical and serological characteristics (Myhr et al. 1991, Pazos et al. 
1993, Santos et al. 1996). Moreover, it has been demonstrated (Santos et al. 1996) that VAR strains can be typed on the basis of heat stable $\mathrm{O}$-antigens and that strains isolated from diseased fish can be grouped into 6 serogroups ( $A, B, C, D, F$, and $G$ ), the serotypes $C$ and $F$ being the predominant types among strains isolated from turbot and cod, respectively. This work reports on the antigenic characterization of VAR organisms isolated from diseased turbot and cod in Spain and Denmark. In addition, pathogenicity for rainbow trout Oncorhynchus mykiss was examined in order to assess the importance of these microorganisms for fish farming.

\section{MATERIALS AND METHODS}

Bacterial strains and growth conditions. In the present work we used 20 strains of Vibrio anguillarumrelated organisms (VAR) isolated from diseased turbot Scophthalmus maximus (9 strains) and cod Gadus morhua (11 strains) in northwestern Spain and Denmark (Table 1). As previously reported (Santos et al. 1996), these strains were identified as $V$. splendidus ( 18 strains) and $V$. pelagius (2 strains) using standard morphological, physiological, and biochemical plate and tube tests (Bryant et al. 1986a, b, Fouz et al. 1990, Myhr et al. 1991)

The bacteria were routinely cultured on tryptic soy agar (TSA, Difco Laboratories, Detroit, MI, USA) supplemented with $1 \% \mathrm{NaCl}$ (TSA-1). Bacterial strains were stored frozen at $-70^{\circ} \mathrm{C}$ in tryptic soy broth containing $1 \% \mathrm{NaCl}$ and $15 \%(\mathrm{v} / \mathrm{v})$ glycerol until tested.
Serological characterization. The serological identity of each strain was confirmed by the slide agglutination test using the heat stable $\mathrm{O}$-antigen $\left(10^{9}\right.$ cells $\mathrm{ml}^{-1}$, McFarland standard No. 3) and rabbit antisera against formalin-killed suspensions of the various strains: RM51 (serogroup A), RC25.1 (serogroup B), RPM30.2 (serogroup C), RM36.1 (serogroup D), 95-372 (serogroup F), and 95-3-88 (serogroup G). The $\mathrm{O}$ antigens were prepared by heating bacterial suspensions of each strain in phosphate buffered saline (PBS, $\mathrm{pH} 7.4$ ) at $100^{\circ} \mathrm{C}$ for $1 \mathrm{~h}$. The basis for serotyping VAR organisms was previously established by Santos et al. (1996). Sera were obtained as described by Sørensen \& Larsen (1986).

Virulence assay. The VAR strains were tested for virulence in fingerling rainbow trout (mean weight, $10 \mathrm{~g}$ ) kept in freshwater at $20^{\circ} \mathrm{C}$ with aeration. The assay was performed by intraperitoneal inoculation of bacterial doses ranging from $10^{2}$ to $10^{8} \mathrm{CFU}$ (colony forming units) per fish as previously described (Toranzo et al. 1987). Control fish were injected with PBS. Mortalities were recorded over a $14 \mathrm{~d}$ period. The degree of virulence, expressed as the 50\% lethal dose ( $\left(\mathrm{LD}_{50}\right)$, was calculated by the method of Reed \& Müench (1938).

Preparation of lipopolysaccharides (LPS) and electrophoresis analysis. LPS from the cell envelope were obtained following basically the method of Hitchcock \& Brown (1983). Briefly, bacterial cultures on TSA-1 were harvested, washed once, and suspended to an optical density (OD) of 0.8 at $650 \mathrm{~nm}$ in PBS. Aliquots of these suspensions $(1.5 \mathrm{ml})$ were centrifuged $(10000 \times \mathrm{g}$ for $5 \mathrm{~min}$ ) and the cell pellets, resuspended in $50 \mu \mathrm{l}$ of

Table 1. Bacterial strains used in the present study. LD su: number of viable cells needed to kill $50 \%$ of inoculated fish in a $14 \mathrm{~d}$ period. The virulence assay was performed by intraperitoneal inoculation of rainbow trout. NT: not tested

\begin{tabular}{|c|c|c|c|c|}
\hline Strain & Species & Origin & Serogroup & Virulence $\left(L D_{50}\right)$ \\
\hline RQ1.2 & Vibro pelagius (bv. I) & Scophthalmus maximus (Spain) & A & $5.0 \times 10^{4}$ \\
\hline RM51 & $V$ pelagius (bv. I) & S. maximus (Spain) & A & $3.0 \times 10^{5}$ \\
\hline $\mathrm{RC} 25.1$ & V. splendidus (bv. I) & S. maximus (Spain) & B & $>9.0 \times 10^{8}$ \\
\hline RPM167.2 & V. splendidus (bv. I) & S. maximus (Spain) & B & NT \\
\hline RPM 30.2 & V. splendidus (bv. I) & S. maxımus (Spain) & $\mathrm{C}$ & $>2.0 \times 10^{8}$ \\
\hline RPM36.1 & V. splendidus (bv. I.) & S. maximus (Spain) & $\mathrm{C}$ & $>1.5 \times 10^{8}$ \\
\hline RPM40.1 & V. splendidus (bv. I) & S. maximus (Spain) & $\mathrm{C}$ & $>3.0 \times 10^{8}$ \\
\hline RPM41.1 & V. splendidus (bv. I) & S. Maximus (Spain) & $\mathrm{C}$ & $>2.0 \times 10^{8}$ \\
\hline RM36.1 & V. splendidus (bv. I) & S. maximus (Spain) & $D$ & NT \\
\hline $95-3-71$ & V. splendidus (bv. I) & Gadus morhua (Denmark) & $F$ & NT \\
\hline $95-3-72$ & V. splendidus (bv. I) & G. morhua (Denmark) & $\mathrm{F}$ & $1.0 \times 10^{4}$ \\
\hline $95-3-74$ & V. splendidus (bv. I) & G. morhua (Denmark) & $\mathrm{F}$ & $6.0 \times 10^{5}$ \\
\hline $95-3-89$ & V. splendidus (bv. I) & G. morhua (Denmark) & $\mathrm{F}$ & $8.4 \times 10^{3}$ \\
\hline $95-3-90$ & V. splendidus (bv. I) & G. morhua (Denmark) & $F$ & $7.0 \times 10^{4}$ \\
\hline $95-3-91$ & V. splendidus (bv. I) & G. morhua (Denmark) & $F$ & $1.0 \times 10^{5}$ \\
\hline $95-3-92$ & $V$ splendidus (bv. I) & G. morhua (Denmark) & $\mathrm{F}$ & $8.0 \times 10^{4}$ \\
\hline $95-3-93$ & V. splendidus (bv. I) & G. morhua (Denmark) & F & NT \\
\hline $95-3-94$ & V. splendidus (bv. I) & G. morhua (Denmark) & $\mathrm{F}$ & NT \\
\hline $95-3-95$ & V. splendidus (bv. I) & G. morhua (Denmark) & F & $7.0 \times 10^{5}$ \\
\hline $95-3-88$ & $V$ splendidus (bv. I) & G. morhua (Denmark) & $\mathrm{G}$ & $1.4 \times 10^{5}$ \\
\hline
\end{tabular}


electrophoresis sample buffer $[12.5 \mathrm{mM}$ Tris- $\mathrm{HCl}$, $\mathrm{pH} 6.8,2 \%$ sodium dodecyl sulphate (SDS), $10 \%$ glycerol, $0.002 \%$ bromophenol blue, and $5 \% 2$-mercaptoethanol], were boiled for $10 \mathrm{~min}$ and treated with $10 \mu \mathrm{l}$ of $2.5 \mathrm{mg} \mathrm{ml}^{-1}$ proteinase $\mathrm{K}$ in sample buffer at $60^{\circ} \mathrm{C}$ for $1 \mathrm{~h}$. Samples $(15 \mu \mathrm{l})$ were electrophoresed in sodium dodecyl sulfate polyacrylamide gels (SDS-PAGE) at constant current (Laemmli 1970). The LPS were silver stained by the procedure of Tsai \& Frasch (1982).

Analysis of cell-envelope proteins. The cell-envelope proteins were prepared from overnight Vibrio cultures grown on TSB-1. The cells were recovered by centrifugation, resuspended in $3 \mathrm{ml}$ of $10 \mathrm{mM}$ Tris buffer containing $0.3 \%(\mathrm{w} / \mathrm{v}) \mathrm{NaCl}(\mathrm{pH} 8.0)$, and sonicated with a Branson sonifier 250 ( $60 \mathrm{~W}, 30 \mathrm{~s}, 3$ times). After centrifugation at $10000 \times g$ for $2 \mathrm{~min}$, the supernatants were transferred to new tubes and centrifuged for $1 \mathrm{~h}$ at $17000 \times \mathrm{g}$ at $4^{\circ} \mathrm{C}$. Total membrane proteins were examined by SDS-PAGE as described for the LPS analysis. Proteins were stained with Coomassie brilliant blue R-250 (Sigma Chemical Co., St. Louis, MO, USA) and the molecular masses (MM) were determined by comparison with a mixture of MM protein markers (Bio-Rad, Richmond, CA, USA).

Immunoblotting analysis of LPS and proteins. Cell envelope components separated by SDS-PAGE were electroblotted from the gels onto nitrocellulose (NC) membranes (Bio-Rad) using the procedures of Towbin et al. (1979). The NC membranes were then separately exposed to the different polyclonal antisera mentioned above. LPS and protein components recognized by the antisera were visualized by reacting the rinsed $\mathrm{NC}$ membranes with goat anti-rabbit IgG alkaline phosphatase conjugate for $1 \mathrm{~h}$ and the appropriate substrate $0.3 \mathrm{mg} \mathrm{ml}^{-1}$ tetrazolium blue and $0.15 \mathrm{mg} \mathrm{ml}^{-1}$ 5-bromo-4-chloro-3-indolyl phosphate toluidine salt in $0.1 \mathrm{M}$ carbonate buffer, $\mathrm{pH}$ 9.8).

\section{RESULTS AND DISCUSSION}

The experimental infections carried out in the present study (Table 1) demonstrated that 10 of 15 (67\%) VAR strains tested were virulent for rainbow trout, showing an $L_{50}$ ranging from $8.4 \times 10^{3}$ to $7 \times 10^{5} \mathrm{CFU}$ per fish. These $\mathrm{LD}_{50}$ values are in the same range as those reported for Vibrio anguillarum strains of pathogenic serogroups O1, O2, and O3 (Toranzo et al. 1987 , Santos et al. 1991, Pazos et al. 1993). Moreover, differences in the degree of virulence were observed between strains of serogroups $C$ and $F$, which are the predominant types detected among $V$. splendidus

Fig. 1. (A) SDS-PAGE electrophoresis of lipopolysaccharide (LPS) components of Vibrio anguillarum-related (VAR) strains isolated from turbot and (B) the corresponding immunoblot using whole cell antiserum against strain RPM 30.2 of serogroup C. Lanes: (1), RQ1.2; (2), RM51; (3), RC25.1; (4), RPM167.2; (5). RPM30.2; (6), RPM36.1; (7), RPM40.1; (8), RPM4 1. 1; (9), RM36.1

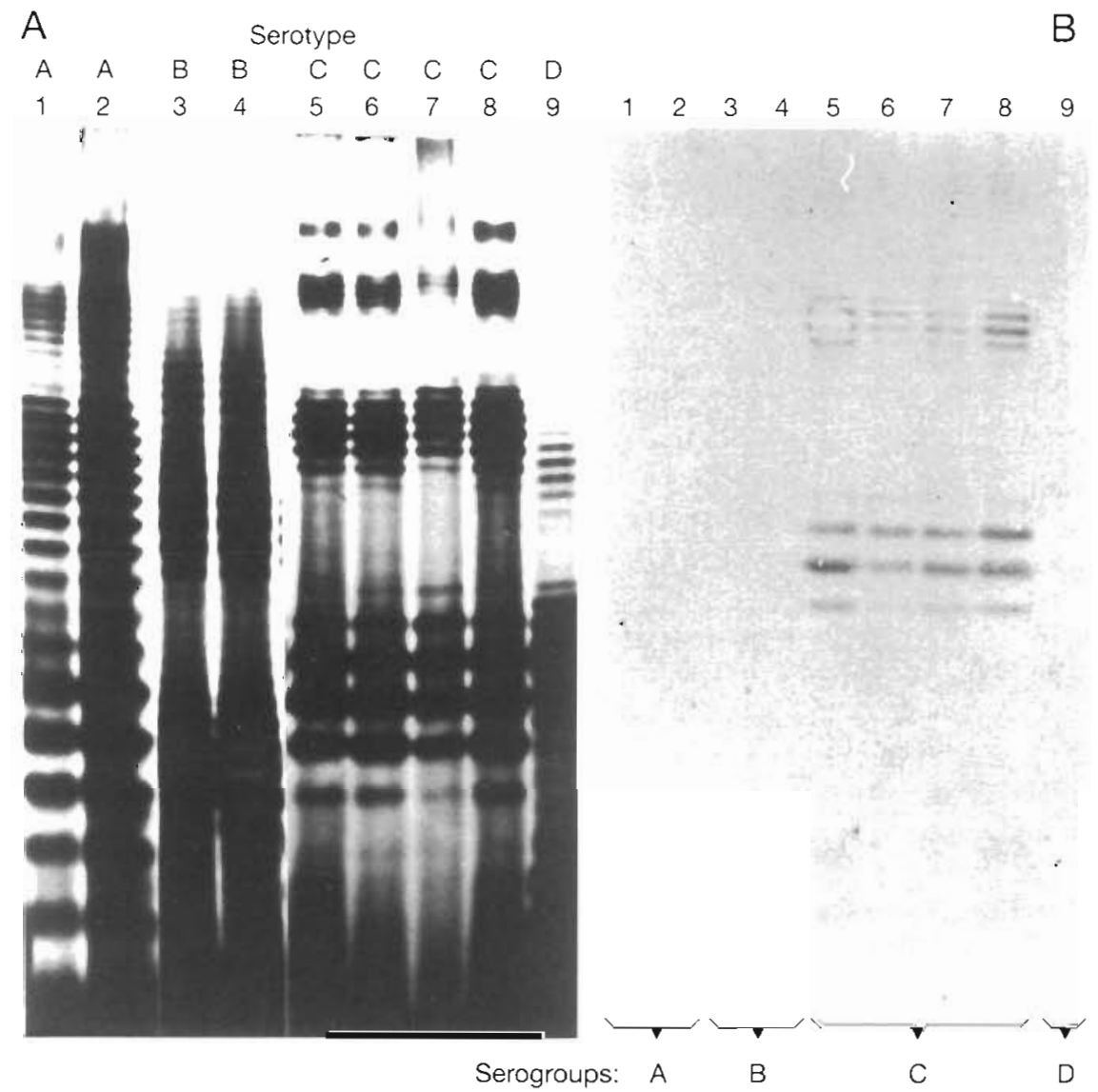




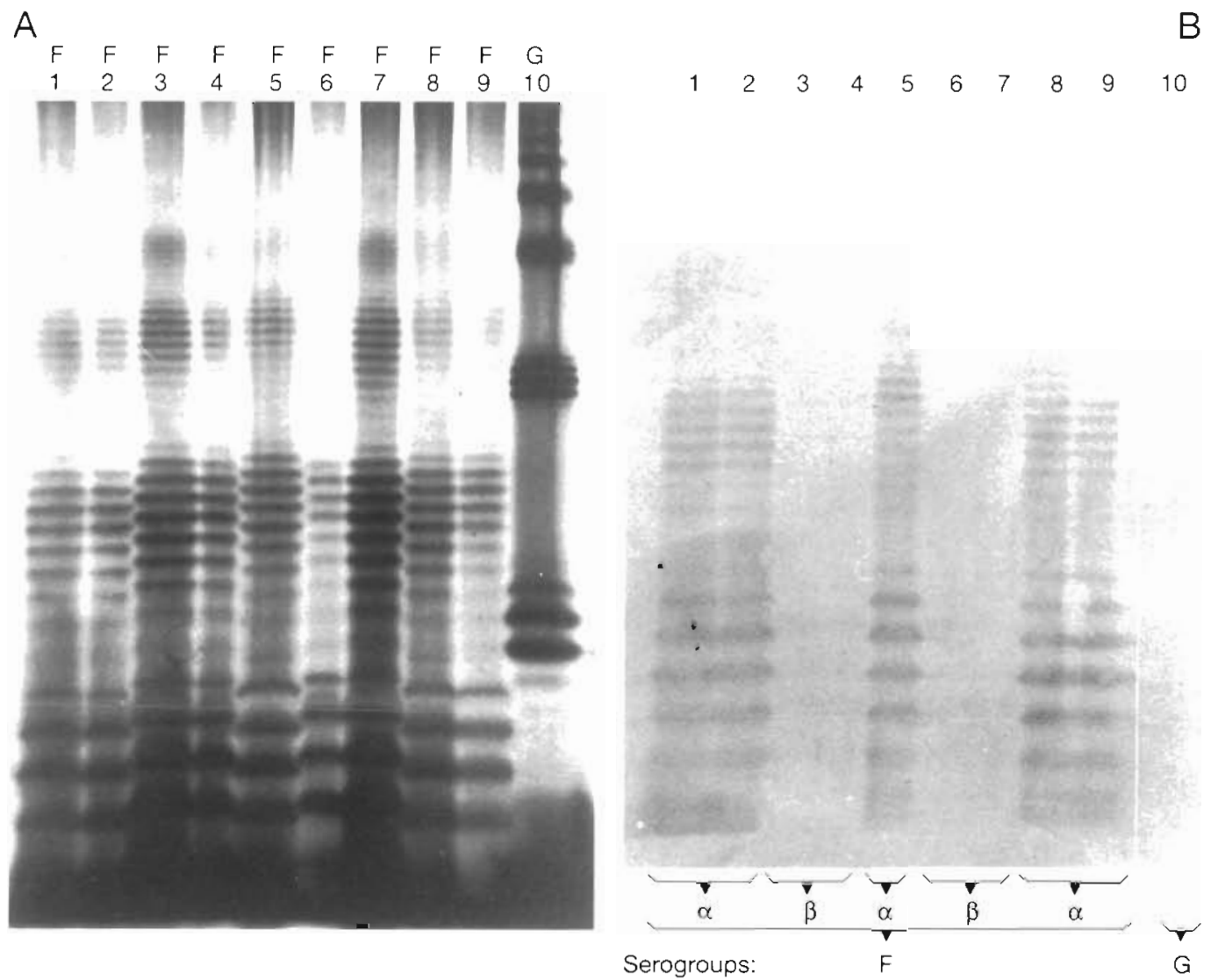

Fig. 2. (A) SDS-PAGE electrophoresis of LPS components of VAR strains isolated from cod and (B) the corresponding immunoblot using whole cell antiserum against strain 95-3-72 (serogroup $F$, subgroup F $\alpha$ ). Lanes: (1), 95-3-72; (2), 95-3-74; (3), 95-3-89; (4), 95-3-90; (5), 95-3-91; (6), 95-3-92; (7), 95-3-93; (8), 95-3-94; (9), 95-3-95; (10), 95-3-88

strains isolated from turbot and cod, respectively (Table 1). Whereas all the $V$. splendidus biovar I strains belonging to the serotype $F$ tested were virulent for fish, avirulent strains predominated among the $V$. splendidus biovar I strains grouped into the serotype $\mathrm{C}$. The $2 \mathrm{~V}$. pelagius biovar I strains (serogroup A) isolated from turbot showed a degree of virulence similar to that found among $V$. splendidus isolated from cod (serogroup F strains). During the course of the experiments, no deaths occurred among the control fish.

The results of the virulence assays indicated that VAR organisms are potentially virulent for salmonid fish. These results differ from those published by Myhr et al. (1991), who reported that VAR strains seem to be of no clinical importance among farmed salmonid fish. However, it must be considered that the experimental challenges used in the present work do not necessarily mimic the natural route of infection.

The analysis of LPS (Figs. 1A \& 2A) showed that, except strain 95-3-88 which belongs to serogroup $G$. all of the VAR isolates tested produced LPS with $\mathrm{O}$ chains of heterogeneous length (i.e. yielded ladderlike patterns). VAR strains belonging to different sero- groups possessed distinct electrophoretic banding patterns (Figs. 1A \& 2A). In general, differences between LPS profiles could be seen in the O-chain pattern as well as in the position of the lipid $A$ and core (the faster migrating bands). Moreover, on the basis of the different mobilities of the LPS components, 2 different profiles (Fig. 2A) were detected within serogroup F, which corresponded with the serological subgroups previously detected using quantitative agglutination assays (Santos et al. 1996). We have designated these serological entities as $F \alpha$ and $F \beta$. The existence of variability in profiles of LPS among strains belonging to different serogroups and diso between strains of the same serotype has been previously reported in Vibrio isolated from salmonid and non-salmonid fish (Nomura \& Aoki 1985, Pazos et al. 1993, Santos et al. 1995). The Western Blot analysis confirmed the dissimilarities in LPS structure observed among the different serogroups as well as between strains belonging to the distinct subgroups of serogroup F. Figs. $1 B$ \& $2 B$ show the immunoblot analysis of LPS from VAR strains isolated from turbot and cod with the antisera against the strain RPM30.2 (serogroup C) and 95-3-72 (serogroup F, subgroup $F \alpha$ ), respectively. 


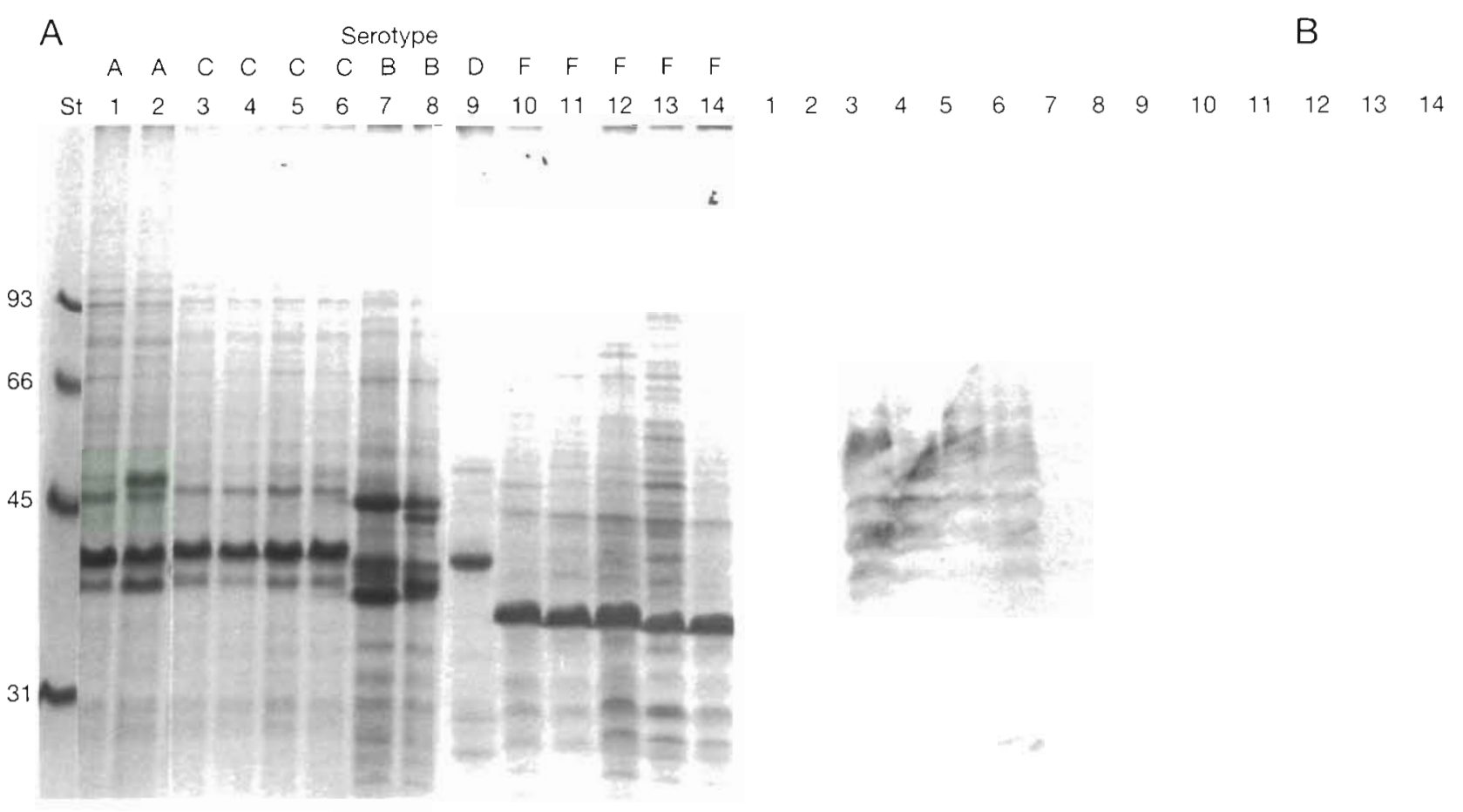

Fig. 3. (A) SDS-PAGE electrophoresis of total membrane proteins of VAR strains isolated from turbot and cod and (B) the corresponding immunoblot using whole cell antiserum against strain RPM30.2 of serogroup C. Lanes: (1), RQ1.2; (2), RM51; (3), RPM30.2; (4), RPM36.1; (5), RPM40.1; (6), RPM41.1; (7), RPM167.2; (8), RC25.1; (9) RM36.1(10), 95-3-72; (11), 95-3-74; (12), 95-3-89; (13), 95-3-90; (14), 95-3-95. St: molecular mass protein markers in kDa

Analysis of cell envelope proteins showed that VAR strains possessed major protein components with molecular weight ranging from approximately 33 to $45 \mathrm{kDa}$ (Fig. 3A). Distinct protein patterns were observed depending on the serotype of the VAR strains. However, minor differences between strains of the same serotype were detected (see Fig. 3, lanes 1 and 2 and lanes 7 and 8). Immunoblot assays revealed that antisera against whole cell of Vibrio splendidus strains of serogroups B, C, D, F, and G reacted strongly only with the membrane proteins of the strains of these serogroups (data shown only for reactions with serotype $\mathrm{C}$ antiserum). None to moderate reactions were observed using sera against $V$. splendidus of heterologous serotypes (Fig. 3B). Similar results were obtained with the whole cell antiserum against the strain of $V$. pelagius RM51 (serogroup A).

The present results suggest that Vibrio splendidus biovar I representative of serogroup $F$ (subgroups $\alpha$ and $\beta$ ) should be included in trial vaccines against vibriosis for use in the cod farming industry. In the case of turbot, additional serological and virulence studies with a larger number including a higher number of VAR organisms are needed to determine if there is a serogroup that should be included in the vibriosis vaccines.
Acknowledgements. This investigation was supported by Grants No. MAR95-1848 from the Comision Interministerial de Ciencia y Tecnología (CICYT) of Spain and XUGA 200049A.94 from the Xunta de Galicia (Spain). The authors are indebted to Dr Larsen (Department of Veterinary Microbiology. The Royal Veterinary and Agricultural University, Denmark) for kindly providing the $V A R$ strains isolated from cod used in this study. F. Pazos thanks the Xunta de Galicia for a research fellowship.

\section{LITERATURE CITED}

Baticados MCL, Lavilla-Pitogo CR, Cruz-Lacierda ER, de la Peña LD, Suñaz NA (1990) Studies on the chemical control of luminous bacteria Vibrio harveyi and $V$. splendidus isolated from diseased Penaus monodon larvae and rearing water. Dis Aquat Org 9:133-139

Bryant TN, Lee JV, West PA, Colwell RR (1986a) Vumerical classification of species of Vibrio and related ynnera. J Appl Bacteriol 61:437-467

Bryant TN, Lee JV, West PA, Colwell RR (1986b) A probability matrix for the identification of species of Vibrio and related genera. J Appl Bacteriol 61:469-480

Castro D, Martínez-Manzanares E, Luque A, Fouz B, Moriñigo MA, Borrego JJ, Toranzo AE (1992) Characterization of strains related to brown ring disease outbreaks in southwestern Spain. Dis Aquat Org 14:229-236

Fouz B, Conchas RD, Bolinches J, Romalde JL, Barja JL, Toranzo AE (1990) Relationship among pathogenic Vibrio anguillarum and Vibrio tubiashii with environmental vib- 
rios. In: Perkins FO, Chen TC (eds) Pathology in marine science. Academic Press, New York, p 7-89

Hitchcock PJ, Brown TM (1983) Morphological heterogeneity among Salmonella lipopolysaccharide chemotypes in silver-stained polyacrylamide gels. J Bacteriol 154:269-272

Knappskog DH, Rodseth OM, Slinde E, Endresen C (1993) Immunochemical analysis of Vibrio anguillarum strains isolated from cod, Gadus morhua, L., suffering from vibriosis. J Fish Dis 16:327-338

Laemli UK (1970) Cleavage of structural proteins during the assembly of the head of bacteriophage T4. Nature 227 : $680-685$

Larsen JL, Pedersen K, Dalsgaard I (1994) Vibrio anguillarum serovars associated with vibriosis in fish. J Fish Dis 17 : $259-267$

Myhr E, Larser. JL, Lillehaug A, Gudding R, Heum M, Håstein T (1991) Characterization of Vibrio anguillarum and closely related species isolated from farmed fish in Norway. Appl Environ Microbiol 57:2750-2757

Nomura J, Aoki T (1985) Morphological analysis of lipopolysaccharide from Gram-negative fish pathogenic bacteria. Fish Pathol 20:1.93-197

Pazos F, Santos Y, Magariños B, Bandín I, Núnez S, Toranzo AE (1993) Phenotypic characteristics and virulence of Vibrio anguillarum-related organisms. Appl. Environ Microbiol 59:2969-2976

Reed LJ, Muench H (1938) A simple method of estimating fifty percent endpoints. Am J Hyg 27:493-497

Riquelme C, Hayashida G, Toranzo AE, Vilches J, Chavez P (1995) Pathogenicity studies on a Vibrio anguillarumrelated (VAR) strain causing an epizootic in Argopecten purpuratus larvae cultured in Chile. Dis Aquat Org 22: $135-141$

Responsible Subject Editor: O. Kinne, Oldendorf/Luhe, Germany
Santos Y, Bandín I, Nunez S, Gravningen $K$, Toranzo AE (1991) Protection of turbot Scophthalmus maximus (L.) and rainbow trout, Oncorhynchus mykiss (Richardson), against vibriosis using two different vaccines. J Fish Dis $14: 407-411$

Santos Y, Pazos F, Bandín I, Toranzo AE (1995) Analysis of antigens present in the extracellular products and cell surface of Vibrio anguillarum serotypes 01,02 , and O3. Appl Environ Microbiol 61:2493-2498

Santos Y, Pazos F, Toranzo AE (1996) Biochemical and serological analysis of Vibrio anguillarum-related organisms. Dis Aquat Org 26:67-73

Sørensen UBS, Larsen JL (1986) Serotyping of Vibrio anguillarum. Appl Environ Microbiol 51:593-597

Toranzo AE, Barja JL (1990) A review of the taxonomy and seroepizootiology of Vibrio anguillarum, with special reference to aquaculture in the northwest of Spain. Dis Aquat Org 9:73-82

Toranzo AE, Santos Y, Bandín I, Romalde JL, Ledo A, Fouz B, Barja JL (1990) A five years survey of bacterial fish infections in continental and marine aquaculture in northwest of Spain. World Aquacult 21:91-93

Toranzo AE, Santos Y, Lemos ML, Ledo A, Bolinches J (1987) Homology of Vibrio anguillarum strains causing epizootics in turbot, salmon and trout reared on the Atlantic coast of Spain. Aquaculture 67:41 -52

Towbin H, Staehelin T, Gordon J (1979) Electrophoretic transfer of proteins from polyacrylamide gels to nitrocellulose sheets: procedure and some applications. Proc Nat Acad Sci 76:4350-4354

Tsal CM, Frasch CE (1982) Staining of lipopolysaccharide in SDS polyacrylamide gels using silver-staining method. Anal Biochem 119:115-119

Manuscript first received: July 11, 1996

Revised version accepted: September 29, 1996 